\title{
Assessment of Ni Toxicity to Fungi and Bacteria in Oil Tainted Soils in Greater Port Harcourt Area, Nigeria
}

\section{1, ${ }^{6}$ WANJALA, MP; ${ }^{2}$ ODOKUMA, L; ${ }^{3}$ ETELA, I; ${ }^{4}$ RAMKAT, R; ${ }^{5}$ ODOGWU, BA; ${ }^{7}$ BOADU, KO; ${ }^{7}$ KORANTENG-ADDO, EJ}

\author{
1 and 2 Department of Microbiology, University of Port Harcourt, Nigeria \\ ${ }^{3}$ Department of Animal Science, University of Port Harcourt, Nigeria \\ ${ }^{4}$ Center of Excellence in Phytochemicals, Textiles and Renewable Energy, Moi University, Eldoret, Kenya \\ ${ }^{5}$ Department of Plant Science and Biochemistry, University of Port Harcourt, Nigeria \\ ${ }^{6}$ Department of Physical and Biological Sciences, Bomet University College, Bomet, Kenya \\ ${ }^{7}$ Industrial Chemistry Unit, Department of Chemistry, University of Cape Coast, Cape Coast, Ghana \\ ${ }^{*}$ Corresponding Author Email: piwanjala@gmail.com, Tel: +254725891794/+2348101149649 \\ Email: Lucky.Odokuma@uniport.edu.ng; ibisime.etela@uniport.edu.ng; chirirose@yahoo.com; blessing.odogwu@uniport.edu.ng; \\ koboadu@ucc.edu.gh; ekoranteng-addo@ucc.edu.gh
}

\begin{abstract}
Intensified urbanization and industrialization are rapidly triggering the release of pollutants to the environment. This study determined the extent of soil contamination with Nickel (Ni) in oil mining areas and its effect on the levels of Ni tolerance by fungi and bacteria. The total CFUs/g of soil were enumerated after a culture period of 7 days at $28^{\circ} \mathrm{C}$ and $\mathrm{LC}_{50}$ was determined using probit and regression analysis. The mean values of $\mathrm{Ni}$ were $1.38 \pm 0.23$ in industrial area, $1.41 \pm 0.36 \mathrm{ppm}$ in agricultural area and 1.02 \pm 0.64 in urban area. The mean values of Total Petroleum Hydrocarbon (TPH) were $4,405.46 \mathrm{ppm}$ in industrial area, $55.65 \mathrm{ppm}$ in agricultural area and $1,304.53 \mathrm{ppm}$ in urban area. Nickel's peak concentration indicating growth of both fungi and bacteria at $150 \mathrm{ppm}$. There was significant difference $(\mathrm{p} \leq 0.000)$ in the mean levels of $\mathrm{LC}_{50}$ for fungi among the study sites. There was no significant correlation between the concentration of TPH in soil and $\mathrm{LC}_{50}$ of fungi $(\mathrm{r}=-0.169)$ and bacteria $(\mathrm{r}=0.042)$. In conclusion, TPH influenced the levels of fungi and bacteria tolerance to $\mathrm{Ni}$ in soils. Moreover, it was observed that $\mathrm{LC}_{50}$ can be a reliable method for monitoring chemically resistant microorganisms directly in the environment to improve the use of microorganisms for the bioremediation of oil contaminated soils and in monitoring of antibiotic resistant microorganisms in natural ecosystems.
\end{abstract}

DOI: https://dx.doi.org/10.4314/jasem.v25i7.18

Copyright: Copyright $\odot 2021$ Wanjala et al. This is an open access article distributed under the Creative Commons Attribution License (CCL), which permits unrestricted use, distribution, and reproduction in any medium, provided the original work is properly cited.

Dates: Received: 10 May 2021; Revised: 28 June 2021; Accepted: 01 July 2021

Key words: Nickel, Tolerance, Toxicity, Bacteria, Fungi, $\mathrm{LC}_{50}$,

Intensified urbanization and industrialization are increasingly releasing heavy metals to the environment. Some of the anthropogenic activities in urban and industrial areas that contribute to excessive release of metals to the environment include; smelting, application of fertilizers and pesticides, burning of fossil fuels, industrial and domestic wastes and mining (Singh, 2001). Increased global demand for crude oil and its products has intensified efforts in petroleum prospecting, mining and transportation processes which go together with spillage and contamination of the environment (Nduka, et al., 2006). Oil spillage is a common occurrence in Nigeria and the worst occurrences are in Niger Delta which is the epicentre of oil mining (Nduka et al., 2006). Some of the metals that are associated with crude oil include; $\mathrm{Al}, \mathrm{As}, \mathrm{Cd}$, $\mathrm{Cr}, \mathrm{Cu}, \mathrm{Hg}, \mathrm{Ni}, \mathrm{Pb}, \mathrm{Se}$ and $\mathrm{Zn}$ (Shtangeeva, 2006). Despite Nickel (Ni) being an essential micronutrient, it may be toxic to animals and humans if consumed in quantities above the recommended thresholds
(McLaughlin et al., 1999). Nickel found in the environment has not only been linked to petroleum, but also to other various sources including; electroplating, zinc base casting and battery industry (Paul, 2017). Nickel is added to gasoline and has been associated with soils on the roadside (Arslan, 2006). Further, Nickel levels in soil vary depending on geology and anthropogenic activities specific to an area. Bacteria can be tolerant to intoxication by nickel, for example; Cupriavidus species (ATHA£), Klebsiella oxytoca (ATHA6) and Methylobacterium spp (ATHA7) have been associated with tolerance for Ni (Alboghobeish, et al., 2014). Smith, (1967), used plasmid (pMOL28) to demonstrate $\mathrm{Ni}$ tolerance in bacteria. There are various ways through which microbes use to absorb metals from the environment. For instance, $\mathrm{Ni}$ enters bacteria and fungi (Saccharomyces cerevisiae) by CorA system (Hmiel et al., 1989). Further, ATP-binding cassette and secondary permeases of NiCo $\mathrm{T}$ family have been 
identified as $\mathrm{Ni}$ transporters in microbial cells for example in Yersinia pseudotuberculosis and Brucella suis (Jubier-Maurin et al., 2001; Sebbane et al., 2002; Eitinger et al., 2005). The rcnA (yohM) gene has been demonstrated to be responsible for Ni efflux (Rodrigue et al., 2005). In some microorganisms eg. Helicobacter pylori, Czn operons have been associated with resistance to $\mathrm{Ni}$ (Stahler et al., 2006). Therefore, fungi can survive in environments contaminated with heavy metals and can detoxify toxins by valence transformation, active uptake, precipitation inside the cells and biosorption (Manguilimotan \& Bitacura, 2018). Microorganisms are non-vertebrates and provide an alternative approach to use of animals in environmental monitoring. This approach is gaining popularity because they are relatively quick, replicable, cheap and do not attract ethical issues (Rotini et al., 2017; Mortensen et al., 2018).

There is variation in terms of availability and abundance of basic requirements for flourishment of microorganisms in various microhabitats and is a major reason for the varying niches with diverse taxa (Grayston, 2001). The type and number of organic substrates available in soil directly translates to abundance of soil microorganisms as well as their diversity in soil (Grayston, 2001). However, there are other factors that contribute on availability and resilience of microorganisms in soil. For instance, spore forming bacteria are more resilient in harsh conditions as they exist in form of spores and can undergo dormancy during the harsh conditions. When conditions are normal, they propagate once again (McKinney, 2004). Lethal Concentration 50 ( LC $\left._{50}\right)$ can be used to study ecotoxicological processes, but hardly has it been applied in environmental monitoring. In toxicology, $\mathrm{LC}_{50}$ is determined where $50 \%$ of organisms die on exposure to a toxic substance (Rotini et al., 2017). The toxic range of a substance may be tested to determine its toxicity range. In this case dose-response relationship is determined followed by determination of $\mathrm{LC}_{50}$. Several methods are available for determination of $\mathrm{LC}_{50}$ (Finney, 1952; OECD, 1981; Paul \& Clark, 1996). This study adopted the Finney, 1952 method where percentage deaths of CFUs/g of soil were determined and linear regression analysis was used to determine $\mathrm{LC}_{50}$ (Manguilimotan \& Bitacura, 2018). The objective of this study is to determine the impact of oil spills to Ni levels on the Greater Port Harcourt Area soils.

\section{MATERIALS AND METHODS}

Description of the Study Site: This study was conducted in 9 selected areas of Port Harcourt, the Capital of Rivers State, Nigeria (Figure 1). The study areas were selected with reference to the economic activities carried out in the areas. The study areas were categorized into 3; (1) urban, (2) Industrial and (3) agricultural. The urban areas included; GRA phase 2, Diobu- Mile 1 and Mguoba, Agricultural areas included; Aluu, Oquwi- Eleme, Emuoha- Eu. Industrial areas included; Eleme which hosts the NNPC Refinery, Agbada-SPDC- flow station in a rural setting and Trans-Amadi. Economic activities (Table 1) conducted in the study areas included; drilling and mining, fishing, fish farming, horticulture, dairy farming and crop farming, industrial processing. The study areas were assigned codes as in Table 1.

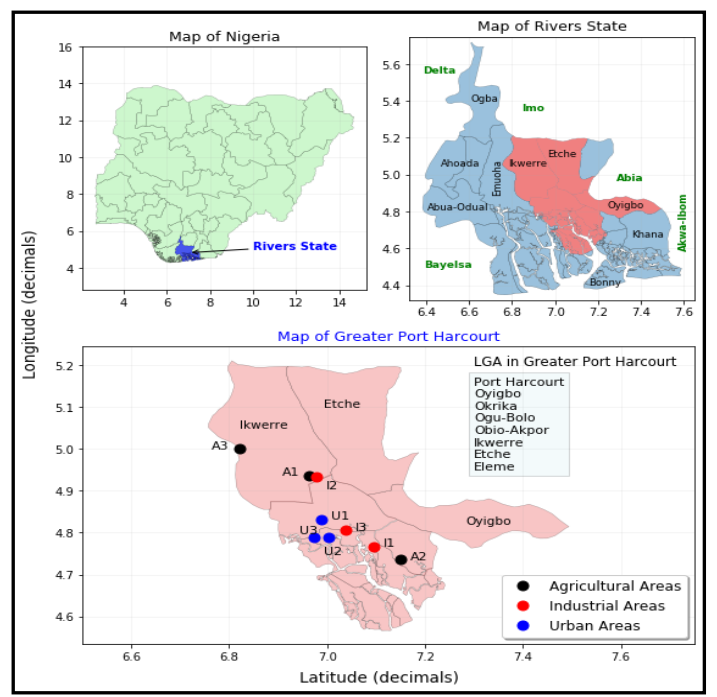

Fig 1: Map of Nigeria showing Location of soil sampling sites in Greater Port Harcourt Area, Rivers State, Nigeria. Different colours show different economic activities (black is agricultural, red is industrial, and blue is urban).

WANJALA, MP; ODOKUMA, L; ETELA, I; RAMKAT, R; ODOGWU, BA; BOADU, KO; KORANTENG$A D D O, E J$ 
Table 1: Study sites, their GPS coordinates and the main economic activities

\begin{tabular}{|c|c|c|c|c|c|}
\hline $\begin{array}{l}\text { Study Area } \\
\text { Coding (sites) }\end{array}$ & No & $\begin{array}{l}\text { Selected } \\
\text { Study Areas }\end{array}$ & $\begin{array}{l}\text { Coordinates } \\
\mathrm{N} \text { latitude } \\
\text { E Longitude }\end{array}$ & & $\begin{array}{l}\text { Characteristic and main } \\
\text { activities }\end{array}$ \\
\hline \multicolumn{6}{|l|}{ Agricultural sites } \\
\hline A1 & 1 & Aluu & $\begin{array}{ll}4^{\circ} & 56^{\prime} \\
6^{\circ} 57^{\prime} & 52.248\end{array}$ & $11.160^{\prime}$ & Flow station \\
\hline $\mathrm{A} 2$ & 2 & Eleme & $\begin{array}{l}4^{\circ} \quad 44^{\prime} \\
7^{\circ} 08^{\prime} 58.494^{\prime}\end{array}$ & 09.874' & $\begin{array}{l}\text { Village close to refinery } \\
\text { Flow station }\end{array}$ \\
\hline A3 & 3 & Emuoha & $\begin{array}{ll}5^{\circ} & 00^{\prime} \\
6^{\circ} 49^{\prime} & 13.032\end{array}$ & $00.018^{\prime}$ & $>1 \mathrm{~km}$ away from suspected \\
\hline $\mathrm{CA}$ & 4 & Control & $\begin{array}{l}5^{\circ} \quad 00^{\prime} \\
6^{\circ} 49^{\prime} 00.000^{\prime}\end{array}$ & $21.384^{\prime}$ & areas/Virgin land \\
\hline \multicolumn{6}{|l|}{ Industrial sites } \\
\hline I1 & 1 & Onne & $\begin{array}{l}4^{\circ} \quad 46^{\prime} \\
7^{\circ} 05^{\prime} 43.092,\end{array}$ & $00.402^{\prime}$ & Hosts the NNPC Refinery \\
\hline $\mathrm{I} 2$ & 2 & Agbada & $\begin{array}{l}4^{\circ} \quad 56^{\prime} \\
6^{\circ} 58^{\prime} 42.060^{\prime}\end{array}$ & $03.444^{\prime}$ & $\begin{array}{l}\text { Hosts SPDC- flow station in a } \\
\text { rural }\end{array}$ \\
\hline $\mathrm{I} 3$ & 3 & Trans-Amadi & $\begin{array}{ll}4^{\circ} & 48^{\prime} \\
7^{\circ} 02 & 17.646\end{array}$ & $20.455^{\prime}$ & $\begin{array}{l}\text { setting } \\
\text { Schlumberger/, Hallburton }\end{array}$ \\
\hline $\mathrm{CI}$ & 4 & Control & $\begin{array}{ll}4^{\circ} & 47^{\prime} \\
7^{\circ} 07^{\prime} & 44.620\end{array}$ & $13.788^{\prime}$ & $\begin{array}{l}>1 \mathrm{~km} \text { away from suspected } \\
\text { areas/Virgin land }\end{array}$ \\
\hline Urban sites & & & & & \\
\hline U1 & 1 & GRA Phase 2 & $\begin{array}{l}4^{\circ} \quad 49^{\prime} \\
6^{\circ} 59^{\prime} 45.552\end{array}$ & $53.574^{\prime}$ & Inhabited areas Perecuma street \\
\hline $\mathrm{U} 2$ & 2 & Diobu-Mile 1 & $\begin{array}{ll}4^{\circ} & 47^{\prime} \\
7^{\circ} 00^{\prime} & 13.164\end{array}$ & $20.382^{\prime}$ & Petroleum refinery \\
\hline U3 & 3 & Mgbuoba & 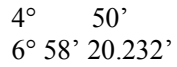 & $39.864^{\prime}$ & NTA Area \\
\hline $\mathrm{CU}$ & 4 & Control & $\begin{array}{l}4^{\circ} \quad 49^{\prime} \\
6^{\circ} 59^{\prime} 24.168^{\prime}\end{array}$ & $17,040^{\prime}$ & $\begin{array}{l}>1 \mathrm{~km} \text { away from suspected } \\
\text { areas/Virgin land }\end{array}$ \\
\hline
\end{tabular}

Sampling: Composite samples were collected by simple random sampling from each of the three study areas: urban, industrial and agricultural during the wet season (April to October 2018). Five (5) individual samples were collected following a random pattern around each study field.

The five individual samples were thoroughly mixed by coning and quartering in a sterile container to attain a homogenous composite mixture. A total of 12 composite samples; A1, A2, A3, I1, I2, I3 U1, U2 and $\mathrm{U} 3$ as test samples, and CA, CI and CU as control samples (Table 1), were collected from the topsoil within a depth of 0 to $15 \mathrm{~cm}$ using a standard auger 3 times in the rainy season.

Homogenized composite samples (400 gm) were then packed in polyethylene bags using a sterile wooden shovel. For microbial analysis, the soil samples were collected using a stainless-steel autoclaved shovel then placed in sterile plastic sample bags (3 M, USA). The soil samples were then transported to the laboratory within 4 hours and preserved at $4{ }^{\circ} \mathrm{C}$ until microbiological analysis had been completed. Locations of the sampling sites were identified using a GPS and coordinate values were recorded. Samples were transported to the laboratory for analysis.
Determination of the levels Nickel: Levels of Ni were determined using Atomic Absorption Spectrum [AAS] (APHA, 2005 \{APHA, 301A\}). Two grams of soil samples were separately weighed for each site and transferred into separate Kjeldahl flasks; $20 \mathrm{ml}$ of concentrated nitric acid $\left(\mathrm{HNO}_{3}\right)$ was added, and the samples pre-digested by heating gently for 20 mins. Afterwards, $10 \mathrm{ml}$ nitric acid was added, and digestion continued for 30-40mins until when a clear digest was obtained. The flask was cooled to room temperature and the content was transferred into $50 \mathrm{ml}$ volumetric flask and brought to volume using distilled water. The resulting solution was analyzed for $\mathrm{Ni}$ using the Atomic Absorption Spectrophotometer (AAS). The heavy metals were then analyzed at the wavelengths 341.5 .

Preparation of Mineral Salt Agar and Potato Dextrose Agar: Mannitol Salt Agar (MSA) (11.10 g) was weighed and dissolved in $100 \mathrm{ml}$ distilled water (as per manufacturer's instructions). The mixture was then sterilized the by autoclaving at $121^{\circ} \mathrm{C}$ for $15 \mathrm{~min}$ then cooled to 50 to $55^{\circ} \mathrm{C}$. The mixture was then well mixed and dispensed aseptically in sterile petri dishes.

Potato Dextrose Agar (PDA) (39 g) powder was weighed and suspend in 1L of distilled water. The mixture was heated and stirred to dissolve all its

WANJALA, MP; ODOKUMA, L; ETELA, I; RAMKAT, R; ODOGWU, BA; BOADU, KO; KORANTENG$A D D O, E J$ 
components. It was then sterilized by autoclaving at $121^{\circ} \mathrm{C}$ for $15 \mathrm{~min}$ then cooled to 50 to $55^{\circ} \mathrm{C}$. The mixture was then well mixed and dispensed aseptically in sterile petri dishes. The plates were stored at 2 to $8^{\circ} \mathrm{C}$ in plastic bags to prevent loss of moisture.

Enumeration of Ni tolerant bacteria: Nickel tolerant bacteria was enumerated by pour plate method (APHA et al., 1998). In this method $1 \mathrm{~g}$ of soil sample was weighed into a $9 \mathrm{ml}$ sterile diluent $(0.85 \% \mathrm{NaCl})$ under aseptic conditions. The sample was then homogenized using a laboratory vortex mixer (Model: 10101001, IP42) and serially diluted. Then, $0.1 \mathrm{ml}$ aliquot of inoculum was inoculated on Mineral Salt Agar (MSA) mixed with antifungal reagent (fungin ${ }^{\mathrm{TM}}$ ) to inhibit the growth of metal tolerant fungi and hydrocarbon utilizing fungi. Fixed dose procedure was used, where microorganisms were dosed in a stepwise procedure using the fixed doses from a range of; 10 ppm, 25 ppm, 50 ppm, 75 ppm, 100 ppm, 150 ppm of Nickel (Ni). The initial dose levels were selected on basis of preliminary study as the dose expected to produce toxicity causing mortality. Plates were then incubated in an inverted position at room temperature ( 23 to $28^{\circ} \mathrm{C}$ ) for 5 to 7 days. Colonies were counted in order to obtain colony forming units per gram of soil.

Enumeration of Ni tolerant fungi: Nickel tolerant fungi was enumerated by pour plate method (APHA et al., 1998). In this method, $1 \mathrm{~g}$ of soil sample was weighed into a $9 \mathrm{ml}$ sterile diluent $(0.85 \% \mathrm{NaCl})$ under aseptic conditions. The sample was then homogenized using a laboratory vortex mixer (Model 10101001, IP42) and serially diluted. Then, $0.1 \mathrm{ml}$ aliquot of inoculum was inoculated on Potato Dextrose Agar (PDA) mixed with an antibacterial reagent (Normocure ${ }^{\mathrm{TM}}$ ) which is a broad-spectrum antibacterial agent highly effective against Gram+ and Gram- bacteria, in order to inhibit the growth of bacteria and allow for only growth of fungi. Fixed dose procedure was used to dose microorganisms in a stepwise procedure using fixed doses of; 10 ppm, 25 ppm, 50 ppm, 75 ppm, 100 ppm and $150 \mathrm{ppm}$ of Nickel (Ni). The initial dose levels were selected on basis of sighting study as the dose expected to produce toxicity effects. Plates were then incubated in an inverted position at room temperature for 5 to 7 days. Colonies were counted to obtain colony forming units per gram of soil (CFUs/g).

Determination of $L C_{50}$ for bacteria and fungi: The percentages of dead organisms in each study concentration were determined and converted to probits. The regression analysis was then carried out and the values obtained from the probit analysis were used to compare the amount of chemical needed to generate responses between microorganisms in different study areas to different concentrations of $\mathrm{Ni}$ in the culture medium (Vincent, 1980). Areas that showed low values of $\mathrm{LC}_{50}$ were considered most toxic as compared to areas that recorded high values of $\mathrm{LC}_{50}$ (Vincent, 1980). Microorganisms in areas with high values of $\mathrm{LC}_{50}$ were considered more tolerant to exposure to the heavy metals. The $\mathrm{LC}_{50}$ was determined by calculating the corresponding $\mathrm{x}$ value for a probit of 5.00 and then taking the inverse log of the concentration it is associated with (Vincent, 1980) as shown in the formula 1 .

$$
\mathrm{y}=\mathrm{ax}+\mathrm{c}
$$

Determination of total petroleum hydrocarbon content of soil: The Hewlett Packard 5890 Series II Gas Chromatograph FID method was used. In this method, $1 \mathrm{~g}$ of well-mixed sample was weighed into Acetone rinsed beaker. Then, $1 \mathrm{~g}$ of anhydrous sodium sulphate was added to the soil sample and $5 \mathrm{ml}$ of solvent $(1: 1$ of dichloromethane and acetone) was added and stirred for 15 min using a magnetic stirrer and the ensuing mixture was poured into a round bottom flask. This was repeated once more by adding $5 \mathrm{ml}$ of mixed solvent. It was stirred and permitted to stand/settle and then decanted into another round bottom flask. The solvent was concentrated with $1 \mathrm{ml}$ hexane to exchange it and it was re-concentrated to $2 \mathrm{ml}$. The columns were eluted (washed off) with $10 \mathrm{ml} \mathrm{n-}$ hexane. One $\mathrm{ml}(1 \mathrm{ml})$ of the extract was pipetted into the column and $10 \mathrm{ml}$ of $\mathrm{n}$-hexane was used to collect the aliphatic components. The extract was concentrated to $1 \mathrm{ml}$ and poured into a glass vial for Gas Chromatography.

Data Analysis: Data was analyzed using IBM SPSS (Version 25.0) software. One Way analysis of variance (ANOVA) was used to evaluate the difference between the $\mathrm{LC}_{50}$ of the contaminated and control sites. Pearson's correlation analysis was used to determine the relationship between the $\mathrm{LC}_{50}$ values and the values of metal concentration and (Total Petroleum Hydrocarbon) TPH in the study areas, and $\mathrm{p} \leq 0.05$ was considered to be the level of confidence.

\section{RESULTS AND DISCUSSION}

Microbial count for the soil and levels of $L C_{50}$ Table 2 shows the observations of mean fungal colony forming units per gram (CFUs/g) of soil in the study sites. The industrial control site (CI) showed growth of $4.00 \times 10^{2}$ CFUs/g of soil at a maximum of $100 \mathrm{ppm}$. Industrial site 1 (I1) showed growth of $6.67 \times 10^{1} \mathrm{CFUs} / \mathrm{g}$ of soil at a maximum concentration of $75 \mathrm{ppm}$. Industrial site 2 (I2) showed growth of $1.80 \times 10^{2} \mathrm{CFUs} / \mathrm{g}$ of soil at a maximum concentration of $150 \mathrm{ppm}$. Industrial site 1 (I3) showed a maximum growth of $1.33 \times 10^{3} \mathrm{CFUs} / \mathrm{g}$

WANJALA, MP; ODOKUMA, L; ETELA, I; RAMKAT, R; ODOGWU, BA; BOADU, KO; KORANTENG$A D D O, E J$ 
of soil at concentration of $100 \mathrm{ppm}$ (Table 2). In the agricultural area, the control sample (CA) showed population of $4.30 \times 10^{2} \mathrm{CFUs} / \mathrm{g}$ of soil at a concentration of $150 \mathrm{ppm}$. Aluu (A1) showed growth of $1.00 \times 10^{2} \mathrm{CFUs} / \mathrm{g}$ of soil at a concentration of 150 ppm. A2 had growth of $6.67 \times 10^{1} \mathrm{CFUs} / \mathrm{g}$ of soil at concentration of $100 \mathrm{ppm}$. Agricultural site 3 (A3) showed a population of $6.67 \times 10^{2} \mathrm{CFUs} / \mathrm{g}$ of soil (Table 3). In urban control area (CU) showed a maximum population of $1.60 \times 10^{3} \mathrm{CFUs} / \mathrm{g}$ of soil at a concentration of $50 \mathrm{ppm}$. Urban site 1 (U2) had a maximum population of $1.00 \times 10^{2} \mathrm{CFUs} / \mathrm{g}$ of soil at 75 ppm. Urban site 2 (U2) had growth of $6.67 \times 10^{1}$ CFUs/g of soil at $150 \mathrm{ppm}$ and Urban site 3 (U3) had a maximum fungal population of $3.03 \times 10^{2} \mathrm{CFUs} / \mathrm{g}$ of soil at $100 \mathrm{ppm}$. Table 4 shows the different mean bacterial colony forming units per gram (CFUs/g) of soil as observed in different concentrations of Ni. In the industrial area, site $\mathrm{CI}$ had population of $7.73 \times 10^{3}$ CFUs/g of soil at a maximum concentration of $75 \mathrm{ppm}$. Site I1 had a population of $1.48 \times 10^{4} \mathrm{CFUs} / \mathrm{g}$ of soil. Site I2 had a population of $1.41 \times 10^{2} \mathrm{CFUs} / \mathrm{g}$ of soil at a maximum concentration of $150 \mathrm{ppm}$. Site I3 had a maximum population of $5.84 \times 10^{3} \mathrm{CFUs} / \mathrm{g}$ of soil at a maximum concentration of $100 \mathrm{ppm}$. In the agricultural areas, control site CA had population of
$1.05 \times 10^{3} \mathrm{CFUs} / \mathrm{g}$ of soil at $100 \mathrm{ppm}$. Site A1 had a population of $6.67 \times 10^{3} \mathrm{CFUs} / \mathrm{g}$ of soil at a maximum concentration of $75 \mathrm{ppm}$. Site A2 had population of $1.00 \times 10^{3} \mathrm{CFUs} / \mathrm{g}$ of soil at $100 \mathrm{ppm}$, while site A3 had growth of $6.67 \times 10^{2} \mathrm{CFUs} / \mathrm{g}$ of soil at $100 \mathrm{ppm}$. In the urban area, control site $\mathrm{CU}$ had a population of $4.07 \times 10^{3} \mathrm{CFUs} / \mathrm{g}$ of soil at a concentration of $75 \mathrm{ppm}$. Site U1 had a population of $3.85 \times 10^{4} \mathrm{CFUs} / g$ of soil at a concentration of $75 \mathrm{ppm}$. Site U2 had a population of $5.00 \times 10^{1} \mathrm{CFUs} / \mathrm{g}$ of soil at a concentration of $150 \mathrm{ppm}$ and site $\mathrm{U} 3$ had population of $4.47 \times 10^{3} \mathrm{CFUs} / \mathrm{g}$ of soil at a concentration of $75 \mathrm{ppm}$. The highest populations of CFUs/g of soil were recorded at a maximum concentration of $150 \mathrm{ppm}$ and was $5.00 \times 10^{1}$ and $1.41 \times 10^{2} \mathrm{CFUs} / \mathrm{g}$ of soil observed in sites I2 and U2 respectively.

Mean Lethal concentration 50 ( $\left.\mathrm{LC}_{50}\right)$ of $\mathrm{Ni}$ in fungi varied between $0.43 \pm 0.05 \mathrm{ppm}$ to $15.05 \pm 5.34 \mathrm{ppm}$. Mean Lethal concentration $50\left(\mathrm{LC}_{50}\right)$ in bacteria varied between $0.73 \pm 0.54 \mathrm{ppm}$ to $1.36 \pm 0.29 \mathrm{ppm}$. There was significant difference $(\mathrm{p} \leq 0.000)$ in mean levels of $\mathrm{LC}_{50}$ of fungi between the study sites (Table 3 ). There was no significant difference $(\mathrm{p}=0.918)$ in mean values of $\mathrm{LC}_{50}$ of bacteria between the study sites (Table 4).

Table 2: Mean CFUs/g of soil Nickel tolerant fungi in different concentrations in Greater Port Harcourt Area, Nigeria

\begin{tabular}{|c|c|c|c|c|c|c|c|c|}
\hline Study site & 0 ppm & 10 ppm & $25 \mathrm{ppm}$ & 50 ppm & $75 \mathrm{ppm}$ & 100 ppm & 150 ppm & $\mathbf{L C}_{50}$ \\
\hline CI & $5.21 \times 10^{4}$ & $1.37 \times 10^{4}$ & $2.40 \times 10^{3}$ & $2.30 \times 10^{2}$ & $1.97 \times 10^{2}$ & $4.00 \times 10^{2}$ & 0 & $0.81 \pm 0.50$ \\
\hline I1 & $6.17 \times 10^{5}$ & $2.53 \times 10^{4}$ & $1.80 \times 10^{3}$ & $1.77 \times 10^{3}$ & $6.67 \times 10^{1}$ & 0 & 0 & $0.43 \pm 0.05$ \\
\hline I2 & $1.32 \times 10^{4}$ & $4.97 \times 10^{3}$ & $2.40 \times 10^{3}$ & $1.33 \times 10^{3}$ & $1.07 \times 10^{3}$ & $8.00 \times 10^{2}$ & $1.80 \times 10^{2}$ & $2.44 \pm 1.02$ \\
\hline I3 & $7.50 \times 10^{4}$ & $4.90 \times 10^{4}$ & $3.33 \times 10^{3}$ & $2.30 \times 10^{3}$ & $1.93 \times 10^{3}$ & $1.33 \times 10^{3}$ & 0 & $1.67 \pm 0.37$ \\
\hline CA & $6.18 \times 10^{3}$ & $4.07 \times 10^{3}$ & $2.70 \times 10^{3}$ & $2.40 \times 10^{3}$ & $2.13 \times 10^{3}$ & $1.80 \times 10^{3}$ & $4.30 \times 10^{2}$ & $15.05 \pm 5.34$ \\
\hline A1 & $1.45 \times 10^{5}$ & $1.23 \times 10^{4}$ & $2.40 \times 10^{3}$ & $8.03 \times 10^{2}$ & $3.63 \times 10^{2}$ & $1.77 \times 10^{2}$ & $1.00 \times 10^{2}$ & $0.60 \pm 0.16$ \\
\hline A2 & $3.27 \times 10^{4}$ & $3.40 \times 10^{3}$ & $1.83 \times 10^{3}$ & $1.13 \times 10^{3}$ & $7.33 \times 10^{2}$ & $6.67 \times 10^{1}$ & 0 & $0.92 \pm 0.26$ \\
\hline A3 & $8.23 \times 10^{3}$ & $4.07 \times 10^{3}$ & $2.77 \times 10^{3}$ & $1.97 \times 10^{3}$ & $1.27 \times 10^{3}$ & $1.10 \times 10^{3}$ & $6.67 \times 10^{2}$ & $6.53 \pm 3.66$ \\
\hline $\mathbf{C U}$ & $7.70 \times 10^{4}$ & $3.93 \times 10^{3}$ & $2.47 \times 10^{3}$ & $1.60 \times 10^{3}$ & 0 & 0 & 0 & $0.65 \pm 0.07$ \\
\hline U1 & $1.44 \times 10^{4}$ & $4.23 \times 10^{3}$ & $2.07 \times 10^{3}$ & $1.80 \times 10^{2}$ & $1.00 \times 10^{2}$ & 0 & 0 & $1.06 \pm 0.29$ \\
\hline U2 & $6.60 \times 10^{4}$ & $5.43 \times 10^{3}$ & $3.23 \times 10^{3}$ & $1.70 \times 10^{3}$ & $1.40 \times 10^{3}$ & $5.60 \times 10^{2}$ & $6.67 \times 10^{1}$ & $1.54 \pm 0.93$ \\
\hline U3 & $6.23 \times 10^{4}$ & $4.23 \times 10^{4}$ & $2.50 \times 10^{3}$ & $1.80 \times 10^{3}$ & $1.13 \times 10^{3}$ & $3.03 \times 10^{2}$ & 0 & $1.40 \pm 0.62$ \\
\hline $\mathbf{p}=$ & & & & & & & & 0.000 \\
\hline
\end{tabular}

Table 3: Mean CFUs/g for soil Nickel tolerant bacteria in different concentrations in Greater Port Harcourt Area, Nigeria

\begin{tabular}{|c|c|c|c|c|c|c|c|c|}
\hline Study site & 0 ppm & 10 ppm & 25 ppm & 50 ppm & 75 ppm & 100 ppm & 150 ppm & LC $_{50}$ \\
\hline I2 & $7.43 \times 10^{6}$ & $3.73 \times 10^{6}$ & $3.81 \times 10^{5}$ & $2.01 \times 10^{5}$ & $7.51 \times 10^{3}$ & $2.83 \times 10^{3}$ & $1.41 \times 10^{2}$ & $1.25 \pm 0.24$ \\
\hline CA & $6.17 \times 107$ & $1.48 \times 10^{7}$ & $2.80 \times 10^{6}$ & $3.93 \times 10^{5}$ & $2.24 \times 10^{5}$ & $1.05 \times 10^{3}$ & 0 & $0.81 \pm 0.29$ \\
\hline A1 & $1.30 \times 10^{6}$ & $6.77 \times 10^{5}$ & $8.53 \times 10^{4}$ & $7.07 \times 10^{3}$ & $6.67 \times 10^{3}$ & 0 & 0 & $1.06 \pm 0.15$ \\
\hline A2 & $7.07 \times 10^{7}$ & $3.37 \times 10^{7}$ & $1.68 \times 10^{6}$ & $2.75 \times 10^{5}$ & $5.37 \times 10^{4}$ & $1.00 \times 10^{3}$ & 0 & $1.11 \pm 0.39$ \\
\hline U1 & $4.57 \times 10^{7}$ & $2.12 \times 10^{7}$ & $1.51 \times 10^{6}$ & $6.17 \times 10^{4}$ & $3.85 \times 10^{4}$ & 0 & 0 & $1.13 \pm 0.42$ \\
\hline U2 & $1.88 \times 10^{7}$ & $6.43 \times 10^{6}$ & $1.42 \times 10^{6}$ & $6.63 \times 10^{5}$ & $5.19 \times 10^{4}$ & $1.63 \times 10^{3}$ & $5.00 \times 10^{1}$ & $1.36 \pm 0.29$ \\
\hline U3 & $1.96 \times 10^{7}$ & $5.77 \times 10^{6}$ & $1.96 \times 10^{5}$ & $1.94 \times 10^{4}$ & $4.47 \times 10^{3}$ & 0 & 0 & $0.73 \pm 0.54$ \\
\hline $\mathbf{p}=$ & & & & & & & & 0.918 \\
\hline
\end{tabular}

Mean soil TPH, Ni and $\mathrm{LC}_{50}$ of contaminated and control sites: Table 4 shows the mean values of the $\mathrm{Ni}$, $\mathrm{TPH}$ and $\mathrm{LC}_{50}$ for fungi and bacteria in the contaminated and control areas. The mean values for
$\mathrm{Ni}$ were $1.38 \pm 0.23$ in industrial area, $1.41 \pm 0.36 \mathrm{ppm}$ in agricultural area and $1.02 \pm 0.64$ in urban area. There was no significant difference $(\mathrm{p}=0.222)$ between the study and control areas. All the values were within

WANJALA, MP; ODOKUMA, L; ETELA, I; RAMKAT, R; ODOGWU, BA; BOADU, KO; KORANTENG$A D D O, E J$ 
permissible limits of WHO of $\leq 50$ (ppm). The mean values for TPH were 4,405.46 ppm in industrial area, $55.65 \mathrm{ppm}$ in agricultural area and $1,304.53 \mathrm{ppm}$ in urban area. The mean values of TPH varied and were oscillating above or within the EPA recommended standard level of $\leq 500 \mathrm{ppm}$. All the mean values of $\mathrm{TPH}$ in the contaminated areas were higher than the
TPH values in the control areas. There was no significant correlation between the concentration of TPH in soil and $\mathrm{LC}_{50}$ for fungi $(\mathrm{r}=-0.169)$ and bacteria $(r=0.042)$ (Table 4). Further, there was no significant correlation between concentrations of $\mathrm{Ni}$ in soil with $\mathrm{LC}_{50}$ of fungi $(\mathrm{r}=0.175)$ and bacteria $(\mathrm{r}=0.079)$ (Table 4).

\begin{tabular}{l} 
Table 4: Comparison of mean levels of Ni and TPH in agricultural, industrial and urban soils of Greater Port Harcourt Area, Nigeria \\
\cline { 2 - 5 }
\end{tabular}

Comparison of mean levels of $L C_{50}$ of fungi and bacteria in agricultural, industrial and urban areas: Figure 2 compares the mean values of $\mathrm{LC}_{50}$ for fungi and bacteria between the contaminated and control sites. The Mean levels of $\mathrm{LC}_{50}$ for fungi and bacteria in agricultural area was $2.68 \pm 3.42$ and $0.97 \pm 0.34 \mathrm{ppm}$ respectively. The Mean levels of $\mathrm{LC}_{50}$ for fungi and bacteria in industrial area was $1.51 \pm 1.03$ and

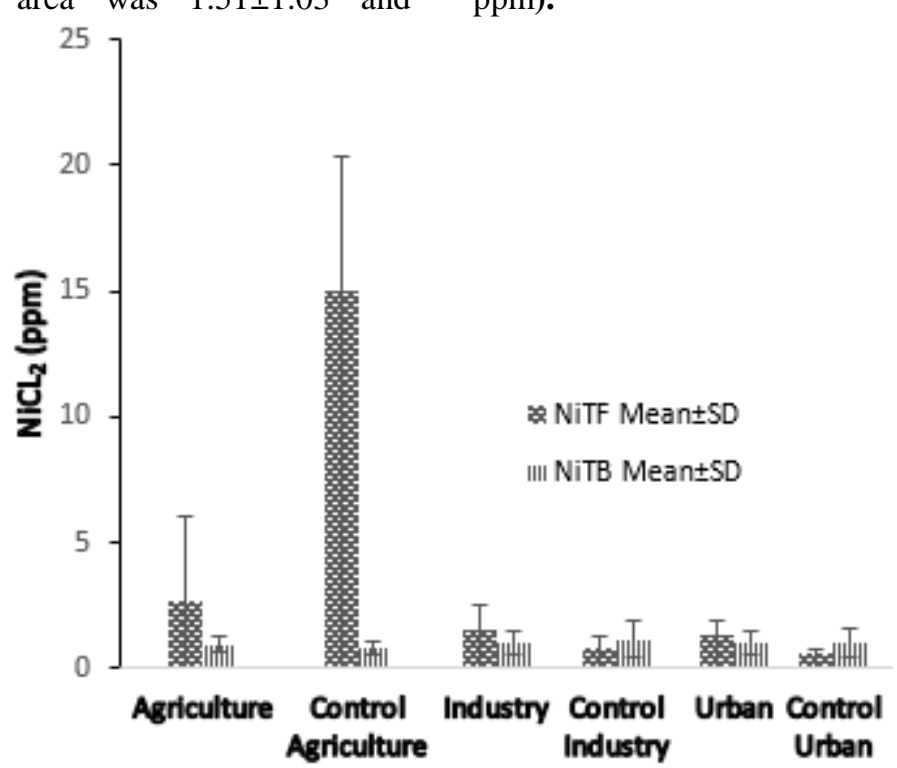

Study Areas
NiTF Mean $\pm S D$

NiTB Mean \pm SD
Urban
$1.08 \pm 0.46 \mathrm{ppm}$ respectively. The Mean levels of $\mathrm{LC}_{50}$ for fungi and bacteria in urban area was $1.33 \pm 0.61$ and $1.07 \pm 0.46 \mathrm{ppm}$ respectively. The highest values of tolerance were observed in fungi in agricultural area which was $2.68 \pm 0.34 \mathrm{ppm}$. Further, the agricultural control area showed higher value $(15.05 \pm 5.34 \mathrm{ppm})$ as compared to the agricultural study site $(2.68 \pm 0.34$ ppm).

Fig 2: Mean levels of $\mathrm{LC}_{50}$ for Ni on fungi and bacteria in agricultural, industrial and urban areas of Greater Port Harcourt Area, Nigeria. $(\mathrm{NiTF}=$ Nickel Tolerant Fungi, NiTB = Nickel Tolerant Bacteria)

Sources of oil contamination in the environment can be grouped as; natural, during exploration/extraction/production and spills in the course of transportation (Hester \& States, 2018). Therefore, anthropogenic activities are a large source of oil to the environment (Ramseur, 2012; Jernelöv, 2018; Wang et al., 2018). Nickel is one of the metals that has been linked to oil sources. Nickel is added in gasoline and has been associated with soils on the roadside (Arslan, 2006). Nickel properties and concentrations in soil are also dependent on soil properties and can also be influenced by anthropogenic activities (Elbana \& Selim, 2019) including mining, fertilizers, sewage, combustion of fossil fuels and 
metal smelting (Gonnelli and Renella, 2013; Wang et al., 2018). In this study, the mean concentrations of $\mathrm{Ni}$ varied among the study areas which agrees with findings of Kabata-Pendias, (2011). Levels of Nickel in soil range between 0 to $80 \mathrm{ppm}$ and vary depending on geology and anthropogenic inputs in an area (Kabata-Pendias, 2011). The variation in values of $\mathrm{Ni}$ in the current study can be linked to the magnitude of pollution by human activities (Mohamed, Shaala, Zahmir, \& Ismail, 2015), as well as retention capacity of the soils (Elbana \& Selim, 2019). Retention of nickel in soil is dependent on a number of factors; $\mathrm{pH}$, soil carbon, clay, silt and $\mathrm{CaCO}_{3}$ content (Elbana \& Selim, 2019). Total Petroleum Hydrocarbon (TPH) were varied among the study areas but did not show any significant relationship to the values of nickel. This implies that the values of Nickel can be linked to other sources including mining, fertilizers, sewage, combustion of fossil fuels and metal smelting (Gonnelli and Renella, 2013; Wang et al., 2018), rather than contamination with oil. Not all crude oils are characterized with high levels of Nickel but rather is varied. The findings of this study agree with those of (John, 2001) which showed varied amounts of contamination of $\mathrm{Ni}$ in crude oil. Crude oil has a concentration of $8 \mathrm{ppm}$ in Kuwait, 9 ppm in Prudhoe Bay in Alaska and $10 \mathrm{ppm}$ in Arab light oil in the Middle East. Contrarily to the low concentration of $\mathrm{Ni}$ in crude oil in some countries, there are other places where crude oil is produced with high concentrations of Ni. These areas include; Beta (Los Angeles Beach) which ranges between 104-166 ppm, Cerro negro (Venezuela) at $118 \mathrm{ppm}$ and California offshore at 166 $\mathrm{ppm}$. This is an indication that crude oil in the study areas had low concentration of $\mathrm{Ni}$, as the tainted soils showed low concentrations that are close to control samples. Therefore, $\mathrm{Ni}$ plays a vital role in classification of petroleum according to the relationship between oil properties and source rock properties (Barwise, 1990).

Highest mean CFUs/g of soil Nickel tolerant fungi was recorded in Agricultural sites at $150 \mathrm{ppm}$. The findings of this study are in agreement with those of Afzal, Rasool, Waseem, \& Aslam in 2017, on the study of tolerance bacterial and fungal isolates to Nickel (Ni) to a maximum concentration of 50\% (Afzal et al., 2017). Tolerance of microorganisms to $\mathrm{Ni}$ varies according to levels of pre-exposure to varied concentrations. Further, the findings agree with those of Renella, (2017), who linked distribution of soil microorganisms to levels of contamination of soil. Microbial populations vary among different locations and increased activity can be related to zones with elevated particulate organic matter, animal manure, in rhizospheres and growth factors (Sexstone et al., 1985;
Parkin, 1987; Petersen et al., 1996; Lynch, 1990; Pinton et al., 2001; Gonnelli and Renella, 2013; Renella, 2017). In the current study there was no significant correlation between $\mathrm{LC}_{50}$ of nickel tolerant bacteria and levels of nickel in the soils of the study sites. Also, there was no significant relationship between $\mathrm{LC}_{50}$ of nickel tolerant fungi and bacteria to levels of TPH among the study sites. Other sources of $\mathrm{Ni}$ in soil include; windblown dust, volcanoes, combustion of oil, incineration of domestic wastes, $\mathrm{Ni}$ refining, production of steel, natural occurrence, electroplating, zinc base casting and battery industry (Gonnelli and Renella, 2013; Paul, 2017). These could be the sources of $\mathrm{Ni}$ in the industrial and urban areas in the current study. However, the levels are within the WHO permissible limits of $\leq 50 \mathrm{ppm}$. Washing off of bacteria and fungi from adjacent ecosystems to the study areas could also be a contributing factor to the varied distribution of $\mathrm{Ni}$ tolerant microorganisms among the study areas (McKinney, 2004). Underground soils, act as reservoirs of varied soil microorganisms which are resilient and emerge when survival conditions are optimal (McKinney, 2004). There is variation in availability and abundance of basic requirements for flourishment of microorganisms in various microhabitats and is a major reason for varying nitches with diverse taxa. The type and quantity of organic substrates available in soil directly translates to abundance of soil microorganisms as well as their diversity in soil (Grayston, 2001). Spore forming bacteria are more resilient in harsh conditions as they exist in form of spores and can undergo dormancy. When conditions are normal, they propagate once again (McKinney, 2004).

Conclusion: The findings in this study reveal the area which harbours Ni tolerant Fungi and bacteria can be useful for selection of microorganisms for bioremediation of $\mathrm{Ni}$ contaminated areas. $\mathrm{Ni}$ was within the recommended limits of $\leq 50 \mathrm{ppm}$ in all study sites. However, the highest values of $\mathrm{LC}_{50}$ for $\mathrm{Ni}$ were observed in the agricultural areas which harbours petroleum activities an indication that farm produce may be contaminated. Also, the study does not associate the levels of $\mathrm{Ni}$ in the soils only to TPH, but other probable sources like natural sources and other human activities like agricultural inputs in the area.

Acknowledgements: This work was carried out within the PhD Program of World Bank African Centre of Excellence for Oilfield Chemicals Research, in line with the World Bank's mandate for establishing the African Centre of Excellence in University of Port Harcourt in Nigeria. The authors further acknowledge the Regional Universities Forum for Capacity

WANJALA, MP; ODOKUMA, L; ETELA, I; RAMKAT, R; ODOGWU, BA; BOADU, KO; KORANTENG$A D D O, E J$ 
Building in Agriculture (RUFORUM) through Prof. Ikechukwu O. Agbagwa of University of Port Harcourt for their continual mentorship and financial support under the Carnegie Post-Doctoral funding (Grant number - RU 2017 TQA 28).

\section{REFERENCE}

Afzal AM, Rasool MH, Waseem M, Aslam B (2017). Assessment of heavy metal tolerance and biosorptive potential of Klebsiella variicola isolated from industrial effluents. $A M B$ Express. 7(184): 184

Alboghobeish H, Tahmourespour A, Doudi M (2014). The study of Nickel Resistant Bacteria (NiRB) isolated from wastewaters polluted with different industrial sources. Journal of Environmental Health Science and Engineering. 34:1-7

APHA (2005). Standard Methods for the Examination of Water and Wastewater. $21^{\text {st }}$ Ed. American Public Health Association, Washington, USA

APHA (1998). Standard Methods for Examination of Water and Wastewater. American Public Health Association, American Water Works Association and Water Pollution Control Federation, 20 ${ }^{\text {th }}$ Edition, Washington DC, USA

Arslan H, Gizir AM (2006). Heavy-metal content of roadside in Mesin, Turkey. Fresenius Environmental Bulletin. 15:15-20

Barwise AJG (1990). Role of nickel and vanadium in petroleum classification. Energy \& Fuels. 4 (6): 647-652.

Eitinger TJ, Suhr J, Moore JA, Smith C (2005). Secondary transporters for nickel and cobalt ions: theme and variations. BioMetals. 18:399-405

Elbana TA, Selim, HM (2019). Modeling of cadmium and nickel release from different soils. Geoderma. 338:78-87

Finney DJ (1952). Probit Analysis. Cambridge, England. Cambridge University Press.

Gonnelli C, Renella G (2013). Chromium and nickel. In: Alloway, B. (Ed.), Heavy Metals in Soils: Trace Metals and Metalloids in Soils and Their Bioavailability, $\quad 3^{\text {rd }}$. Springer, Dordrecht Heidelberg New York London, pp. 313-333

Grayston SJ, Griffith GS, Mawdsley JL, Campbell CD, Bardgett RD (2001). Accounting for variability in soil microbial communities of temperate upland grassland ecosystems. Soil Biology and Biochemistry. 33: 533-551

Hester MW, States U (2018). Oil Spills in Coastal Wetlands. Encyclopedia of the Anthropocene. Elsevier Inc.

Hmiel SP, Snavely MD, Florer JB, Maguire ME, Miller CG (1989). Magnesium transport in Salmonella typhimurium: genetic characterization and cloning of three magnesium transport loci. $J$ Bacteriol. 171, 4742-4751

Jernelöv A (2018). Environmental Effects of Terrestrial Oil Spills. Encyclopedia of the Anthropocene. Elsevier Inc

John GR (2001). Nickel in Petroleum Refining. Petroleum Science and Technology. 19:7-8, 9791007

Jubier-Maurin VA, Rodrigue S, Ouahrani-Bettache M, Layssac, MA; Mandrand-Berthelot S, Kohler, Liautard JP (2001). Identification of the nik gene cluster of Brucella suis: regulation and contribution to urease activity. J. Bacteriol. 183:426-434

Kabata-Pendias A (2011). Trace Elements in Soils and Plants, 4th ed. CRC Press, Boca Raton, FL, USA

Li S, Xu Q, Ma B, Guo L, She Z, Zhao Y, Gao M, Jin C, Dong J, Wan Y (2017). Performance evaluation and microbial community of a sequencing batch reactor under divalent cadmium (II) stress. Chem. Eng. J. 336, 325-333.

Lynch JM (1990). The Rhizosphere. John Wiley \& Sons, Chichester. 28 (2).458

Manguilimotan LC, Bitacura JG (2018). Biosorption of Cadmium by Filamentous Fungi Isolated from Coastal Water and Sediments. Journal of toxicology

McKinney RE (2004). Environmental Pollution Control Microbiology. New York: Marcel Dekker, Inc. pp 464

McLaughlin M.J, Parker DR, Clarke JM (1999). Metals and micronutrients - food safety issues. Field Crops Res. 60:143-163

Mohamed N, Shaala A, Zahmir S, Ismail A (2015). Lethal concentration 50 ( $\mathrm{LC}_{50}$ ) and effects of Diuron on morphology of brine shrimp; Artemia

WANJALA, MP; ODOKUMA, L; ETELA, I; RAMKAT, R; ODOGWU, BA; BOADU, KO; KORANTENG$A D D O, E J$ 
salina (Branchiopoda: Anostraca) Nauplii. Procedia Environmental Sciences. 30, 279-284

Mortensen LH, Rønn R., Vestergård M (2018). Bioaccumulation of cadmium in soil organisms With focus on wood ash application. Ecotoxicology and Environmental Safety. 156, 452-462

Organization of Economic Cooperation and Development [OECD] (1981). OECD Guidelines for Testing Chemicals. OECD Publication Service, Paris

Parkin TB (1987). Soil microsites as a source of denitrification variability. Soil Science Society of America Journal. 51, 1194-1199

Paul D (2017). Annals of Agrarian Science Research on heavy metal pollution of river Ganga: A review. Annals of Agrarian Sciences. 7(21), 1-9

Paul EA, Clark FE (1996). Soil Microbiology and Biochemistry, $2^{\text {nd }}$ Edition. Academic Press, San Diego. 453.

Petersen SO, Nielsen TH, Frostegard A, Olesen T (1996). Q2 uptake, C metabolism and denitrification associated with manure hot spots. Soil Biology \& Biochemistry. 28, 341-349

Pinton R, Varanini Z, Nannipieri P (2001). The Rhizosphere: Bio- chemistry and Organic Substances at the Soil - Plant Interface. Marcel Dekker, New York. pp.viii + 424 pp

Ramseur JL (2012). Oil spills in U.S. coastal waters: Background and governance. CRS report RL33705. Washington, DC: Congressional Research Service. Saba VS and Spotila JR (2003) Survival and behavior of freshwater turtles after rehabilitation from an oil spill. Environmental Pollution. 126: 213-223

Rodrigue A, Effantin G, Berthelot MAM (2005). Identification of renA (yohM a Nickel and Cobalt Resistance Gene in Escherichia coli. Jour. Bacteriol. 187(8) p. 2912-2916
Rotini A, Manfra L, Spanu F, Pisapia M, Cicero AM, Migliore L (2017). Ecotoxicological Method with Marine Bacteria (Vibrio anguillarum) to evaluate the Acute Toxicity of Environmental Contaminants. J. Visualized Experiments. (123), 15.

Sebbane F, Mandrand-Berthelot MA, Simonet M (2002). Genes encoding specific nickel transport systems flank the chromosomal urease locus of pathogenic yersiniae. J. Bacteriol. 184, 2002 :5706- 5713.

Sexstone AJ, Revsbech NP, Parkin TB, Tiedje JM (1985). Direct measurement of oxygen profiles and denitrification rates in soil aggregates. Soil Science Society of America Journal. 49, 645-651.

Singh B (2001). Heavy metals in soils: sources, chemical reactions and forms. In: D. Smith, et al., (Eds.), Geotechnics: Proceedings of the Second Australia and New Zealand Conference on Environmental Geotechnics, Newcastle, Australia. pp. 77-93.

Smith DH (1967). R factors mediate resistance to mercury, nickel and cobalt. Science. 156, 11141116.

Stahler FN, Odenbreit S, Haas R, Wilrich J, Van Vliet AH, Kusters JG, Kist M, Bereswill S (2006). The novel Helicobacter pylori CznABC metal efflux pump is required for cadmium, zinc, and nickel resistance, urease modulation, and gastric colonization. Infect Immun. 74, 2006 3845-3852.

Vincent BK (1980). Probit Analysis.

Wang XQ, Wei DP, Ma YB, Mclaughlin MJ (2018). Soil ecological criteria for nickel as a function of soil properties. Environ. Sci. Pollut. Res. 25, 21372146. 